\title{
PHENOTYPICAL CONSOLIDATION OF FIRSTBORN COWS OF UKRAINIAN RED-AND-WHINE DAIRY BREED OF DIFFERENT GENEALOGICAL FORMATIONS BY CONFORMATION TYPE
}

\author{
Khmelnychyi Leontii Mykhailovych \\ Doctor of Agricultural Sciences, Professor \\ Sumy National Agrarian University \\ ORCID: 0000-0001-5175-1291 \\ E-mail: khmelnychy@ukr.net \\ Anisimova Olha Anatoliivna \\ Master's student of the Faculty of Biology and Technology \\ Sumy National Agrarian University \\ ORCID: 0000-0003-1744-5455 \\ E-mail: olhaanisimovaz@gmail.com \\ Kompanets Ihor Olehovych \\ Master's student of the Faculty of Biology and Technology \\ Sumy National Agrarian University \\ ORCID: 0000-0002-3153-1491 \\ E-mail: igorokkompanets@gmail.com \\ Lemeshko Dymytrii Oleksandrovych \\ Master's student of the Faculty of Biology and Technology \\ Sumy National Agrarian University \\ ORCID: 0000-0003-4730-6202 \\ E-mail: Idmitry2724@gmail.com \\ Perekuta Oleksandra Ivanivna \\ Master's student of the Faculty of Biology and Technology \\ Sumy National Agrarian University \\ ORCID: 0000-0003-3019-1859 \\ E-mail: Alexandra.Perekuta@gmail.com
}

The phenotypic consolidation of firstborn cows Ukrainian Red-and-White dairy breed of different lines by conformation type was studied. Cows were evaluated according to the method of linear classification in the herd of breeding farm PAE "Piskivs'ke" Bakhmatsky district of Chernihiv region. The degree of phenotypic consolidation of lines was determined by formulas of Yu. P. Polupan (2005). Regardless of the line representation, the highest degree of phenotypic consolidation was found in the set of traits that characterize udder with coefficients ranging from $K=0.200$ (Inganse line) to $K=0.393$ (Kevelie line). According to the complex of conformation traits that characterize expression of dairy type in cows, the best were consolidated daughter descendants of Inganse $(K=0.309)$ and Kevelie lines $(K=0.335)$. Offsprings of two pedigree lines Siteishn $(K=0.015)$ and $R$. Sovering $(K=0.049)$ have a low degree of phenotypic consolidation by set of dairy-type body parts. A similar situation in determining the degree of phenotypic consolidation was observed for a group of body parts characterizing body development. The best consolidated were animals Inganse $(K=0.267)$ and Kevelie $(K=0.395)$, and the worst - Siteshn $(K=0.048)$ and Valiant $(K=0.042)$ lines. According to the assessment of descriptive traits within studied lines, following body parts were distinguished by positive values of phenotypic consolidation coefficients : rump height $(K=0.127-273)$, body depth $(K=0.092-0.328)$, rear width $(K=0.033-0.363)$, front udder part attachment $(K=$ $0.041-0.227)$, dairy type $(K=0.143-0.385)$, and negative - hooves condition $(K=-0.264 \ldots-0.046)$. Analyzing the results of research, it can be argued that practical application of phenotypic consolidation coefficients as objective evaluation criteria will allow in the future to control consolidation of genealogical formations and other breeding groups of animals both by conformation type and another selection traits.

Key words: Ukrainian Red-and-White dairy breed, line, firstborn cow, phenotypic consolidation, linear assessment, conformation.

DOl: https://doi.org/10.32845/bsnau.lvst.2020.4.2

Phenotypic and genetic specificity and a certain degree of consolidation are important characteristics and prerequisites for approbation and further genetic progress of breeds and their structural selection units $[9,16,13,15]$. Achieving the desired level of phenotypic consolidation of intrabreed selection formations first of all required presence of a genetically grounded and, at the same time, simple and affordable to calculate its

evaluation criteria. Such were proposed by Yu. P. Polupan [14] coefficients of phenotypic consolidation, based on the assessment of relative narrowing of intragroup variability, are gradually gaining recognition and becoming more widespread for practical evaluation of this biological population process. The effectiveness of improving effect of evaluated traits of a particular selection group of animals was determined not only by better value 
estimates and level of phenotypic consolidation, depending on the degree of genetic variability of traits. The use of phenotypic consolidation coefficients allowed to objectively differentiate different selection groups of animals according to the degree of phenotypic consolidation of selection traits that characterize reproductive ability $[6,12,24]$, milk productivity $[5,26]$, lifetime use [1], constitutional types [18] and conformation of animals $[10,11,20,23,21]$.

According to one of classical definitions, line - an objectively existing group of breeding animals with certain valuable qualities, which come from a high-value breeder and for many generations retain the type of ancestor, its productive and breeding qualities [2]. That is, the main feature of line was its inherent consolidation in economically useful traits due to kinship and targeted selection, making the line somewhat different from others. Conformation-constitutional features in this regard were one of indicators by which representatives of lines often differ from each other $[4,7,8,11,20,25]$.

Given the existing problem, a methodological aspect emerged, which consisted in the development and use of an objective criterion for determining the degree of consolidation of selection formations on the leading economically useful features, which was proposed to use phenotypic consolidation coefficients. Which allowed the real selection material to sufficiently differentiate different selection groups of animals according to the degree of phenotypic consolidation of economically useful traits that are important for animal breeding [3, 17, 19].

Given the problem, we consider it necessary to continue the practical testing of methods to determine the degree of phenotypic consolidation of leading genealogical formations in Ukrainian Red-and-White dairy breed for linear traits that characterize conformation type of animals.
Materials and research methods. Classification daughters of sires of different lines was performed in the herd of pedigree farm PAE "Piskivske" Bakhmatsky district of Chernihiv region for breeding Ukrainian Red-and-White dairy breed. The firstborn cows were evaluated according to the method [22], by a 100-score system of linear classification with a separate presentation of estimates of four sets of conformation traits that characterize the expression of dairy type, body development, limb condition and udder quality, and nine-score a scale of individual descriptive body parts of the conformation.

The degree of phenotypic consolidation of lines was determined using the formula of Yu. P. Polupan [13]:

$$
K=1 \frac{\sigma g}{\sigma_{o}}
$$

where: $\sigma_{g}$ - standard deviation estimated group of animals on a particular trait,

$\sigma_{0}$ - the same indicator of general population.

Research results. The experimental groups included the most numerous offspring of sires of six lines - Valiant 1650414, R. Sovering 0198998, Inganse 343514, Heneve 162939, R. Siteishn 267150 and Kevelie 1620273.

From the literature it is known that the main feature of line is the inherent consolidation of its representatives by certain economically useful traits due to kinship and targeted selection, which makes the line somewhat different from others. Conformation type in this regard is one of indicators by which lines often differ from each other. According to the 100-scale classification system, which includes the assessment of four sets of conformation traits that characterize the dairy type, body development, limb condition and udder morphological traits, some of them have the desired level of phenotypic consolidation of animals within lines and conformation complexes (Table 1).

Table 1

The degree of phenotypic consolidation of genealogical formations of Ukrainian Red-and-White dairy breed by 100 -score type classification system

\begin{tabular}{|c|c|c|c|c|c|c|}
\hline \multirow{2}{*}{ Conformation's trait } & \multicolumn{2}{c|}{ Linear affiliation } \\
\cline { 2 - 8 } & $\begin{array}{c}\text { Valiant } \\
1650414\end{array}$ & $\begin{array}{c}\text { R. Sovering } \\
0198998\end{array}$ & $\begin{array}{c}\text { Inganse } \\
343514\end{array}$ & $\begin{array}{c}\text { Heneve } \\
1629391\end{array}$ & $\begin{array}{c}\text { Siteishn } \\
267150\end{array}$ & $\begin{array}{c}\text { Kevelie } \\
1620273\end{array}$ \\
\hline Number of animals, heads & 155 & 39 & 33 & 78 & 115 & 39 \\
\hline $\begin{array}{c}\text { Set of traits that characterizes: } \\
\text { dairy type }\end{array}$ & 0,103 & 0,049 & 0,309 & 0,113 & 0,015 & 0,335 \\
\hline body & 0,042 & 0,100 & 0,267 & 0,172 & 0,048 & 0,395 \\
\hline limbs & 0,100 & 0,086 & 0,294 & 0,300 & 0,110 & 0,179 \\
\hline udder & 0,220 & 0,355 & 0,200 & 0,203 & 0,224 & 0,393 \\
\hline Final score & 0,259 & 0,145 & 0,309 & 0,314 & 0,266 & 0,385 \\
\hline
\end{tabular}

Regardless of line representation, the highest degree of phenotypic consolidation was found in firstborn cows of Ukrainian Red-and-White dairy breed according to a set of morphological traits characterizing the udder with coefficients ranging from $K=0.200$ (Inganse line) to $K=0.393$ (Kevelie line).

According to complex of conformation traits that characterize expression of cows dairy type, the best consolidated daughter descendants of Inganse $(K=0.309)$ and Kevelie $(K=$ 0.335) lines. Offspring of two pedigree lines Siteishn ( $K=0.015)$ and $\mathrm{R}$. Sovering $(K=0.049)$ have a low degree of phenotypic consolidation by the set of dairy-type body parts.

A similar situation in determining the degree of phenotypic consolidation was observed for a group of body parts characterizing body development. Animals of Inganse $(K=$
$0.267)$ and Kevelie $(K=0.395)$ lines were better consolidated, and Siteshn $(K=0.048)$ and Valiant $(K=0.042)$ lines were the worst.

According to the main conformation traits of descriptive system of linear estimation within a separate representation of experimental lines, there was a significant variation, (Table 2). Only two groups of firstborn cows from the six estimated lines of Ukrainian Red-and-White dairy breed belonging to Inganse 343514 and Kevelie 1620273 lines have an absolute advantage over the others in the phenotypic consolidation of all assessed traits, with variability of phenotypic coefficients from 0.3 and 0.385 , on the basis of dairy type, to $K=0.067$ and 0.101 - on the basis of hock joint angle. 
The degree of phenotypic consolidation of genealogical formations of Ukrainian

Red-and-White dairy breed by 100 -score system of describing linear traits

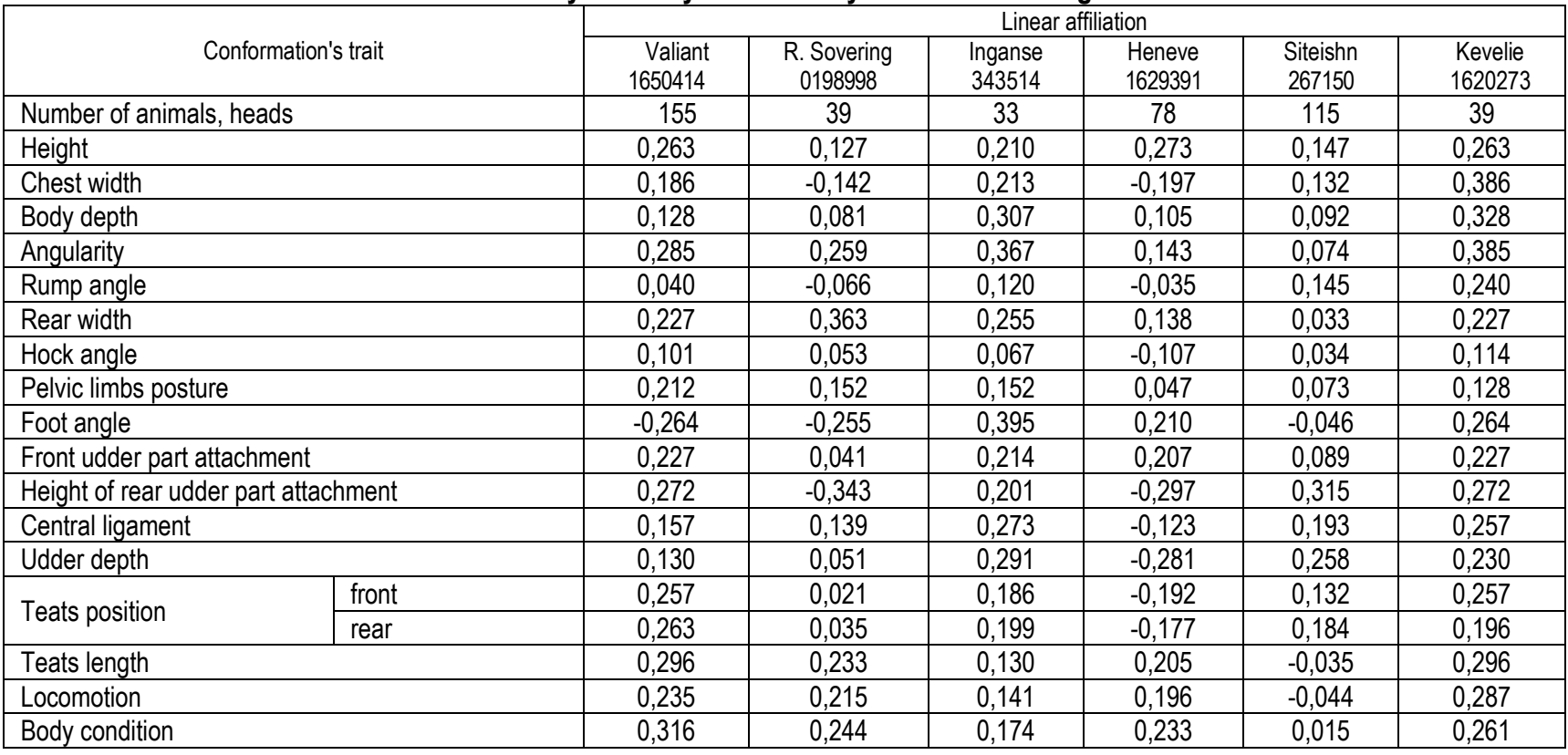

If we consider each individual descriptive trait of conformation type within the studied lines, following values differed in the positive values of coefficients of phenotypic consolidation: rump height $(K=0.127-273)$, body depth $(K=0.092-0.328)$, rear width $(K=0.033-0.363)$, front udder part attachment $(K=0.041$ $0.227)$, dairy type $(K=0.143-0.385)$, and negative - foot condition $(\mathrm{K}=-0.264 \ldots-0.046)$.

A high level of consolidation was found in the groups of descendants of pedigree lines Inganse 343514 and Kevelie 1620273 for development of morphological traits that characterize the quality of udder. The highest degree of phenotypic consolidation was observed by the trait of front udder part attachment $(K=0.207$ and 0.227$)$, and height of rear udder part attachment $(K=0.201$ and 0.272$)$. Sufficiently high levels of phenotypic consolidation were observed for severity of central ligament $(K=0.273$ and 0.257$)$, udder depth $(K=0.291$ and 0.230 ) and teats position ( $K=0.186$ and 0.257$)$. However, these genealogical formations were mostly consolidated by body structure strength $(K=0.213$ and 0.386$)$ and dairy type ( $K=$ 0.367 and 0.385 ).

Thus, the use of proposed coefficients in practice allowed to reliably and simply differentiate animal lines by the degree of phenotypic consolidation, but for final decision on the prospects of a genealogical formation, it is desirable to supplement the selection information with quantitative indicators.

In this particular case, when significant interlinear varia- bility of phenotypic consolidation indicators was detected, there is a corresponding variability in absolute indicators of conformation traits, positive (desirable) or negative (undesirable) development of which was almost always combined with positive or negative coefficients.

This conclusion was confirmed by most indicators of linear classification (Table 3 ).

Descendants of pedigree line Kevelie 1620273, which with high levels of consolidation coefficients for complexes of conformation body parts by 100 -score rating ( $\mathrm{K}=0.179-0.385$ ) were consolidated on the same traits, expressed in absolute terms, which amounted to $82.3-84.3$ score out of 88 possible for cows firstborn.

Animals of Inganse line 343514, which also had the highest coefficients of phenotypic consolidation in terms of complex linear traits, were better estimated in scores, which amounted to 82.1-83.9 score.

According to linear estimation of 9-score scale of descriptive traits, the same pattern was observed when the highest scores were obtained in the groups of cows firstborn of pedigree lines Kevelie 1620273 and Inganse 343514, which had the best phenotypic consolidation coefficients, (Table 4).

In terms of body depth, descendants of pedigree lines Kevelie 1620273 and Inganse 343514 with an assessment of 6.9-7.4 score prevailed animals of other lines on 1.0-2.2 score with a reliability at $P<0.01-0.001$. 


\section{Characteristics firstborns of estimated lines Ukrainian Red-and-White dairy breed by 100 -score system of type classification,}

$(x \pm$ S.E., score $)$

\begin{tabular}{|c|c|c|c|c|c|c|}
\hline \multirow{2}{*}{ Conformation's trait } & \multicolumn{4}{|c|}{ Linear affiliation } & $\begin{array}{c}\text { Siteishn } \\
267150\end{array}$ & $\begin{array}{c}\text { Kevelie } \\
1620273\end{array}$ \\
\cline { 2 - 7 } & Valiant 1650414 & $\begin{array}{c}\text { R. Sovering } \\
0198998\end{array}$ & Inganse 343514 & $\begin{array}{c}1629391 \\
115\end{array}$ & 39 \\
\hline Number of animals, heads & 155 & 39 & 33 & 78 & $79,1 \pm 0,21$ & $83,3 \pm 0,37$ \\
\hline $\begin{array}{c}\text { Set of traits that characterizes: } \\
\text { dairy type }\end{array}$ & $80,7 \pm 0,19$ & $78,8 \pm 0,21$ & $82,1 \pm 0,36$ & $79,9 \pm 0,34$ & 74 \\
\hline body & $81,6 \pm 0,19$ & $81,4 \pm 0,22$ & $83,1 \pm 0,32$ & $81,1 \pm 0,31$ & $79,8 \pm 0,20$ & $84,2 \pm 0,37$ \\
\hline limbs & $81,4 \pm 0,17$ & $79,7 \pm 0,19$ & $82,3 \pm 0,25$ & $80,6 \pm 0,26$ & $80,6 \pm 0,18$ & $82,3 \pm 0,34$ \\
\hline udder & $80,5 \pm 0,21$ & $82,3 \pm 0,24$ & $83,9 \pm 0,35$ & $80,2 \pm 0,29$ & $81,3 \pm 0,19$ & $84,1 \pm 0,30$ \\
\hline Final score & $81,0 \pm 0,15$ & $80,9 \pm 0,25$ & $83,5 \pm 0,22$ & $80,4 \pm 0,20$ & $80,6 \pm 0,16$ & $84,3 \pm 0,29$ \\
\hline
\end{tabular}

\section{Characteristics firstborns of estimated lines Ukrainian Red-and-White dairy breed by 9 -score system describing linear traits,}

Table 4

( $x \pm$ S.E., score)

\begin{tabular}{|l|c|c|c|c|c|c|}
\hline \multirow{2}{*}{ Conformation's trait } & \multicolumn{5}{c|}{ Linear affiliation } \\
\cline { 2 - 6 } & $\begin{array}{c}\text { Valiant } \\
50414\end{array}$ & $\begin{array}{c}\text { R. Sovering } \\
0198998\end{array}$ & $\begin{array}{c}\text { Inganse } \\
343514\end{array}$ & $\begin{array}{c}\text { Heneve } \\
1629391\end{array}$ & $\begin{array}{c}\text { Siteishn } \\
267150\end{array}$ & $\begin{array}{c}\text { Kevelie } \\
1620273\end{array}$ \\
\hline Number of animals, heads & 155 & 39 & 33 & 78 & 115 & 39 \\
\hline Rump height & $4,6 \pm 0,10$ & $5,1 \pm 0,16$ & $6,0 \pm 0,17$ & $3,6 \pm 0,16$ & $5,5 \pm 0,11$ & $6,9 \pm 0,22$ \\
\hline Body depth & $5,9 \pm 0,10$ & $6,4 \pm 0,17$ & $6,9 \pm 0,18$ & $5,2 \pm 0,16$ & $5,2 \pm 0,12$ & $7,4 \pm 0,21$ \\
\hline Rear position & $4,9 \pm 0,07$ & $4,7 \pm 0,14$ & $4,6 \pm 0,15$ & $5,3 \pm 0,11$ & $5,0 \pm 0,10$ & $4,4 \pm 0,16$ \\
\hline Rear width & $4,9 \pm 0,13$ & $5,2 \pm 0,19$ & $6,4 \pm 0,26$ & $3,6 \pm 0,23$ & $5,4 \pm 0,14$ & $6,6 \pm 0,23$ \\
\hline Hock angle & $5,2 \pm 0,07$ & $5,4 \pm 0,17$ & $5,0 \pm 0,15$ & $5,4 \pm 0,11$ & $5,0 \pm 0,11$ & $4,9 \pm 0,13$ \\
\hline Feet & $4,9 \pm 0,06$ & $5,1 \pm 0,10$ & $5,0 \pm 0,11$ & $4,8 \pm 0,12$ & $4,7 \pm 0,09$ & $5,0 \pm 0,18$ \\
\hline Front udder part attachment & $6,0 \pm 0,08$ & $6,2 \pm 0,13$ & $6,9 \pm 0,14$ & $5,9 \pm 0,13$ & $5,5 \pm 0,10$ & $6,8 \pm 0,19$ \\
\hline Height of rear udder part attachment & $4,4 \pm 0,13$ & $4,8 \pm 0,21$ & $5,1 \pm 0,34$ & $4,9 \pm 0,16$ & $4,6 \pm 0,14$ & $5,2 \pm 0,38$ \\
\hline Central ligament & $4,9 \pm 0,13$ & $5,5 \pm 0,26$ & $6,0 \pm 0,35$ & $4,9 \pm 0,20$ & $5,2 \pm 0,16$ & $6,3 \pm 0,27$ \\
\hline Udder depth & $5,5 \pm 0,10$ & $5,6 \pm 0,19$ & $6,7 \pm 0,22$ & $5,6 \pm 0,13$ & $5,4 \pm 0,12$ & $6,6 \pm 0,21$ \\
\hline Teats position & $3,5 \pm 0,12$ & $5,1 \pm 0,17$ & $5,4 \pm 0,21$ & $4,7 \pm 0,19$ & $5,7 \pm 0,13$ & $6,7 \pm 0,20$ \\
\hline Teats length & $5,7 \pm 0,08$ & $5,2 \pm 0,16$ & $6,1 \pm 0,15$ & $5,6 \pm 0,15$ & $5,3 \pm 0,11$ & $5,2 \pm 0,13$ \\
\hline Strength & $5,6 \pm 0,11$ & $6,1 \pm 0,19$ & $6,7 \pm 0,24$ & $5,9 \pm 0,17$ & $6,4 \pm 0,12$ & $6,8 \pm 0,27$ \\
\hline Dairy type & $5,5 \pm 0,10$ & $6,0 \pm 0,20$ & $7,0 \pm 0,19$ & $4,9 \pm 0,16$ & $5,8 \pm 0,14$ & $7,1 \pm 0,18$ \\
\hline
\end{tabular}

Group of animals of estimated best lines Kevelie 1620273 and Inganse 343514 was distinguished by high scores for traits, which had a high degree of consolidation: rear width (6.4 and 6.6 score), feet condition (5.0 score), front udder part attachment (6.9 and 6.8 score), central ligament (6.0 and 6.3 score), udder depth (6.7 and 6.6 score), strength (6.7 and 6.8 score) and dairy type (7.0 and 7.1 score).

Analyzing the results of research, it can be argued that the practical application of phenotypic consolidation coefficients as objective evaluation criteria will allow in the future control the consolidation of genealogical formations and other breeding groups of animals both by conformation type and other selection traits.

Conclusions. 1. The introduction into the practice of se- lection work of the method of determining the degree of phenotypic consolidation of animal's selection groups will allow to objectively differentiate the genealogical formations of controlled herds according to the features of conformation type.

2. The phenotypic manifestation of conformation traits, expressed by positive and negative coefficients of phenotypic consolidation, characterizes the hereditary qualities of sires of evaluated line.

3. The prospect of further research on this issue should be aimed at the wider application of phenotypic consolidation coefficients involving different breeding groups of animals and to determine the optimal (desired) level of consolidation in the structural units of breeds.

\section{References:}

1. Boiko, Yu. M., 2011. Fenotypova konsolidatsiia linii ukrainskoi buroi molochnoi porody za oznakamy dovichnoho vykorystannia [Phenotypic consolidation of lines Ukrainian Brown dairy breed by traits of longevity use]. Visnyk Sumskoho NAU. Seriia: "Tvarynnytstvo". Sumy, issue 7(18), pp. 101-103.

2. Borisenko, E. Ya., 1967. Razvedenie sel'skokhozyaystvennykh zhivotnykh [Breeding of farm animals]. Moskva: Kolos.

3. Verbych, I. V. and Dubyna, O. V., 2000. Konsolidatsiia henealohichnykh formuvan u podilskomu zavodskomu typi ukrainskoi chorno-riaboi molochnoi porody [Consolidation of genealogical formations in the Podolsk pedigree type of Ukrainian Black-and-White dairy breed]. Mizhvidomchyi tem. zb. nauk. prats Cherkaskoho instytutu APV. K.: Ahrarna nauka, issue 2, pp. 3840.

4. Ignatov, A. V. and Kokhanov, M. A., 2009. Osobennosti ekster'era korov-pervotelok raznykh liniy [Conformation features of firstborn cows of different lines]. Izvestiya Nizhnevolzhskogo agrouniversitetskogo kompleksa, issue 3(15), pp. 77-80. 
5. Ivanov, I. A. and Malenivska, S. P., 2012. Prohnozuvannia dovichnoi molochnoi produktyvnosti koriv ukrainskoi chornoriaboi molochnoi porody [Prediction of lifetime milk productivity of cows Ukrainian Black-and-White dairy breed]. Suchasni problemy selektsii, rozvedennia ta hihiieny tvaryn : zb. nauk. prats Vinnytskoho NAU. Vinnytsia, issue 5(67), pp. 111-114.

6. Iliashenko, H. D., 2012. Konsolidatsiia za osnovnymy hospodarsko korysnymy oznakamy u stadakh ukrainskoi chervonoi i chorno-riaboi molochnykh porid [Consolidation by the main economically useful traits in the herds of Ukrainian Red-and Black-andWhite dairy breeds]. Rozvedennia i henetyka tvaryn. K. : Naukovyi svit, issue 46, pp. 126-128.

7. Kibkalo, L. I., Tkacheva, N. I. and Goncharova, N. A., 2015. Ekster'ernye osobennosti i molochnaya produktivnost' golshtinskikh korov gollandskoy i nemetskoy selektsii [Conformation features and milk productivity of Holstein cows Dutch and German selection] Vestnik Kurskoy GSA. Kursk, issue 3, pp. 51-58.

8. Kohut, M. I. and Bratiuk, V. M., 2013. Kharakterystyka eksterieru koriv osnovnykh linii zakhidnoi vnutrishnoporodnoi populiatsii ukrainskoi molochnoi chorno-riaboi porody [Characteristics of cows conformation of the main lines of Western intrabreed population Ukrainian Black-and-White dairy breed]. Peredhirne ta hirske zemlerobstvo i tvarynnytstvo. Lviv, issue 55(2), pp. 138141.

9. Burkat, V. P. and Polupan, Yu. P. eds., 2002. Konsolidatsiia selektsiinykh hrup tvaryn: teoretychni ta metodychni aspekty. Materialy tvorchoi dyskusii. K.: Ahrarna nauka.

10. Kochuk-Yashchenko, O. A., 2016. Linear assessment of cows conformation of Ukrainian Black- and Red-and-White dairy breeds and its relationship with productivity. Abstract of Ph.D. dissertation : spets. 06.02.01 „Rozvedennia ta selektsiia tvaryn". Chubynske.

11. Kochuk-Yashchenko, O. A., 2014. Liniina otsinka typu i molochna produktyvnist koriv ukrainskoi chorno-riaboi molochnoi porody riznoi liniinoi nalezhnosti [Linear assessment of the type and dairy productivity of cows Ukrainian Black-and-White Dairy breed of different linear affiliation]. Zbirnyk naukovykh prats' Vinnyts'koho NAU, issue 1(83), pp. 139-149.

12. Pelekhatyi, M. S. and Kochuk-Yashchenko, O. A., 2014. Vplyv henotypu koriv-pervistok ukrainskoi chorno-riaboi molochnoi porody na yikh eksteriernyi typ, molochnu produktyvnist i vidtvornu zdatnist [Genotype influence of cows firstborn Ukrainian Black-and-White dairy breed on their conformation type, milk productivity and reproductive ability]. Nauk. visnyk LNUVMB im. S. Z. Hzhytskoho. Lviv, no. (3), pp. 143-158.

13. Polupan, Yu. P., 2005. Metody vyznachennia stupenia fenotypovoi konsolidatsii selektsiinykh hrup tvaryn [Methods for determining the degree of phenotypic consolidation of breeding groups of animals]. Metodyky naukovykh doslidzhen iz selektsii, henetyky ta biotekhnolohii u tvarynnytstvi. K.: Ahrarna nauka, pp. 52-60.

14. Polupan, Yu. P., 1996. Otsenka stepeni fenotipicheskoy konsolidatsii genealogicheskikh grupp zhivotnykh [Assessment of the degree of phenotypic consolidation genealogical groups of animals]. Zootekhniya, issue 10, pp. 13-15.

15. Polupan, Yu. P., 2001. Problemy konsolidatsii riznykh selektsiinykh hrup tvaryn [Problems of consolidation of different breeding groups of animals]. Visnyk ahrarnoi nauky, no. 12, pp. 42-46.

16. Polupan, Yu. P., Rieznykova, N. L. and Havrylenko, M. S., 2010. Vyznachennia fenotypovoi konsolidovanosti selektsiinykh hrup tvaryn na populiatsiinomu rivni [Determination of phenotypic consolidation of selection groups of animals at the population level]. Metodolohiia naukovykh doslidzhen z pytan selektsii, henetyky ta biotekhnolohii u tvarynnytstvi : materialy nauk.-teoret. konf., prysviachenoi pamiati akad. UAAN V. P. Burkata. K.: Ahrarna nauka, pp. 98-100.

17. Polupan, Yu. P., 2000. Povtoryaemost' i vzaimosvyaz' instrumental'noy i glazomernoy otsenki ekster'era krupnogo rogatogo skota [Repeatability and interrelation of instrumental and visual assessment of the cattle conformation]. Sel'skokhozyaystvennaya biologiya, no. 2, pp. 108-114.

18. Stoliar, Zh., V., 2014. Fenotypova konsolidatsiia hrup koriv riznykh typiv konstytutsii [Phenotypic consolidate groups of cows of different types of constitution]. Rozvedennia i henetyka tvaryn : mizhvid. temat. nauk. zb. K. : Ahrarna nauka, issue 48, pp. $129-136$.

19. Suprun, I. O., 2003. Konsolidovanist selektsiinykh oznak koriv vysokoproduktyvnoho stada ukrainskoi chervono-riaboi molochnoi porody [Consolidation of cow's breeding traits of highly productive herd of Ukrainian Red-and-White dairy breed]. Visnyk Sumskoho NAU. Seriia "Tvarynnytstvo". Sumy, issue 7, pp. 237-241.

20. Khmelnychyi, L. M., 2013. Fenotypova konsolidatsiia koriv ukrainskoi chervono-riaboi molochnoi porody riznykh linii za eksteriernym typom [Phenotypic consolidation of Ukrainian Red-and-White dairy cows of different lines by conformation type]. Visnyk Sumskoho NAU. Seriia "Tvarynnytstvo". Sumy, issue 1, pp. 5-9.

21. Khmelnychyi, L. M., 2006. Fenotypova konsolidatsiia selektsiinykh hrup tvaryn ukrainskoi chervono-riaboi molochnoi porody za eksteriernym typom [Phenotypic consolidation of animal's selection groups of Ukrainian Red-and-White dairy breed by conformation type]. Visnyk Cherkaskoho instytutu APV. Cherkasy, issue 6, pp. 101-115.

22. Khmelnychyi, L. M., Ladyka, V. I., Polupan, Yu. P. and Salohub, A. M., 2008. Metodyka liniinoi klasyfikatsii koriv molochnykh i molochno-miasnykh porid za typom [The method of linear classification cows of dairy and dairy-beef breeds by type]. Sumy: VVP "Mriia-1" TOV.

23. Khmelnychyi, L. M., Khmelnychyi, S. L., Loboda, A., V. and Klymenko, O. I., 2019. Phenotypic consolidation of genealogical formations of Sumy intrabreed type of Ukrainian Black-and-White dairy breed on the traits of linear conformation assessment [Fenotypova konsolidovanist henealohichnykh formuvan sumskoho vnutrishnoporodnoho typu ukrainskoi chorno-riaboi molochnoi porody za oznakamy liniinoi otsinky eksterieru]. Rozvedennia $i$ henetyka tvaryn. K., issue 58, pp. 72-79. DOI: https://doi.org/10.31073/abg.58.1079

24. Tsereniuk, O. M., Martyniuk, I. M., Akimov, O. V., Shkavro, N. M. and Khmelnychyi, L. M., 2019. Phenotypic consolidation coefficients of fertility index of Welsh sows [Koefitsiienty fenotypovoi konsolidatsii pokaznyku bahatoplidnosti 
svynomatok uelskoi porody]. Visnyk Sumskoho NAU. Seriia "Tvarynnytstvo". Sumy, issue 1-2(36-37), pp. 102-106. DOI: https://doi.org/10.32845/bsnau.lvst.2019.1-2.15

25. Cherniak, N. H. and Honcharuk, O. P., 2011. Eksterier koriv chorno-riaboi molochnoi porody riznykh linii [Conformation cows of Black-and-White dairy breed of different lines]. Tvarynnytstvo Ukrainy, issue 1/2(21), pp. 22-25.

26. Shcherbatyi, Z. Ye., Pavliv, B. A. and Bodnar, P. V., 2010. Stupin konsolidatsii selektsiinykh oznak koriv okremykh linii stada ukrainskoi chorno-riaboi molochnoi porody [The degree of consolidation breeding traits of cows individual lines herd Ukrainian Black-and-White dairy breed]. Nauk. visnyk LNUVM im. S. Z. Hzhytskoho. Lviv, no. 2(44), pp. 275-279.

\section{Список використаної літератури:}

1. Бойко Ю. М. Фенотипова консолідація ліній української бурої молочної породи за ознаками довічного використання. Вісник Сумського НАУ. Серія: “Тваринництво”. Суми, 2011. Вип. 7(18). С. 101-103.

2. Борисенко Е. Я. Разведение сельскохозяйственных животных. М.: Колос, 1967. 463 с.

3. Вербич І. В., Дубина О. В. Консолідація генеалогічних формувань у подільському заводському типі української чорно-рябої молочної породи. Міжвідомчий тем. зб. наук. праць Черкаського інституту АПВ. К.: Аграрна наука, 2000. Вип. 2. С. 38-40.

4. Игнатов А. В., Коханов М. А. Особенности экстерьера коров-первотелок разных линий. Известия Нижневолжского агроуниверситетского комплекса. 2009. Вып. 3(15). С. 77-80.

5. Іванов І. А., Маленівська С. П. Прогнозування довічної молочної продуктивності корів української чорно-рябої молочної породи. Сучасні проблеми селекції, розведення та гігієни тварин : зб. наук. праць Вінницького НАУ. Вінниця, 2012. Вип. 5(67). С. 111-114.

6. Іляшенко Г. Д. Консолідація за основними господарсько корисними ознаками у стадах української червоної і чорнорябої молочних порід. Розведення і генетика тварин. К. : Науковий світ, 2012. Вип. 46. С. 126-128.

7. Кибкало Л. И., Ткачева Н. И., Гончарова Н. А. Экстерьерные особенности и молочная продуктивность голштинских коров голландской и немецкой селекции. Вестник Курской ГСА. Курск, 2015. Вып. 3. С. 51-58.

8. Когут М. І., Братюк В. М. Характеристика екстер'єру корів основних ліній західної внутрішньопородної популяції української молочної чорно-рябої породи. Передгірне та гірське землеробство і тваринництво. Львів, 2013. Вип. 55(2). С. 138141.

9. Консолідація селекційних груп тварин: теоретичні та методичні аспекти. Матеріали творчої дискусї / За ред. В. П. Бурката і Ю. П. Полупана. К.: Аграрна наука, 2002. 58 с.

10. Кочук-Ященко О. А. Лінійна оцінка екстер'єру корів українських чорно-рябої і червоно-рябої молочних порід та її зв'язок з продуктивністю : автореф. дис. на здобуття наук. ступеня канд. с.-г. наук : спец. 06.02 .01 „Розведення та селекція тварин". Чубинське, 2016. 21 с.

11. Кочук-Ященко О. А. Лінійна оцінка типу і молочна продуктивність корів української чорно-рябої молочної породи різної лінійної належності. Збірник наук. праць Вінницького НАУ. Вінниця, 2014. Вип. 1(83), т. 2. С. 139-149.

12. Пелехатий М. С., Кочук-Ященко О. А. Вплив генотипу корів-первісток української чорно-рябої молочної породи на їх екстер'єрний тип, молочну продуктивність і відтворну здатність. Наук. вісник ЛНУВМ ім. С.3. Гжицького. Львів, 2014. Т. 16, № 3, ч. 3. С. $143-158$.

13. Полупан Ю. П. Методи визначення ступеня фенотипової консолідації селекційних груп тварин. Методики наукових досліджень із селекції, генетики та біотехнології у тваринництві. К.: Аграрна наука, 2005. С. 52-60.

14. Полупан Ю. П. Оценка степени фенотипической консолидации генеалогических групп животных. Зоотехния. 1996. Вып. 10. С. $13-15$.

15 Полупан Ю. П. Проблеми консолідації різних селекційних груп тварин. Вісник аграрної науки. 2001. № 12. С. 42-46.

16. Полупан Ю. П., Рєзникова Н. Л., Гавриленко М. С. Визначення фенотипової консолідованості селекційних груп тварин на популяційному рівні. Методологія наукових досліджень з питань селекції, генетики та біотехнології у тваринництві : матеріали наук.-теорет. конф., присвяченої пам'яті акад. УААН В. П. Бурката, (Чубинське, 25 лютого 2010 р.). К. : Аграрна наука, 2010. С. 98-100.

17. Полупан Ю.П. Повторяемость и взаимосвязь инструментальной и глазомерной оценки экстерьера крупного рогатого скота. Сельскохозяйственная биология. 2000. № 2. С. 108-114.

18. Столяр Ж. В. Фенотипова консолідація груп корів різних типів конституції. Розведення і генетика тварин : міжвід. темат. наук. зб. К. : Аграрна наука, 2014. Вип. 48. С. 129-136.

19. Супрун І. О. Консолідованість селекційних ознак корів високопродуктивного стада української червоно-рябої молочної породи. Вісник Сумського НАУ. Серія “Тваринництво”. Суми. 2003. Вип. 7. С. 237-241.

20. Хмельничий Л. М. Фенотипова консолідація корів української червоно-рябої молочної породи різних ліній за екстер'єрним типом. Вісник Сумського НАУ. Серія: “Тваринництво”. Суми, 2013. Вип. 1. С. 5-9.

21. Хмельничий Л. М. Фенотипова консолідація селекційних груп тварин української червоно-рябої молочної породи за екстер'єрним типом. Вісник Черкаського інституту АПВ. Черкаси, 2006. Вип. 6. С. 101-115.

22. Хмельничий Л. М., Ладика В. І., Полупан Ю. П., Салогуб А. М. Методика лінійної класифікації корів молочних і молочно-м'ясних порід за типом. Суми: ВВП “Мрія-1” ТОВ, 2008. - 28 с.

23. Хмельничий Л.М., Хмельничий С. Л., Лобода А. В., Клименко О. І. Фенотипова консолідованість генеалогічних формувань сумського внутрішньопородного типу української чорно-рябої молочної породи за ознаками лінійної оцінки екстер'єру. Розведення і генетика тварин. - К. 2019. Вип. 58, С. 72-79. DOI: https://doi.org/10.31073/abg.58.1079 
24. Церенюк О. М., Мартинюк І. М., Акімов О. В., Шкавро Н. М., Хмельничий Л. М. Коефіцієнти фенотипової консолідації показнику багатоплідності свиноматок уельської породи. Вісник Сумського національного аграрного університету. Серія «Тваринництво». - 2019. - Вип. 1-2(36-37). - C.102-106. DOl: https://doi.org/10.32845/bsnau.lvst.2019.1-2.15

25. Черняк Н. Г., Гончарук О. П. Екстер'єр корів чорно-рябої молочної породи різних ліній. Тваринництво України. 2011. Вип. 1/2(21). С. $22-25$.

26. Щербатий 3. Є., Павлів Б. А., Боднар П. В. Ступінь консолідації селекційних ознак корів окремих ліній стада української чорно-рябої молочної породи. Наук. вісник ЛНУВМ ім. С. 3. Гжицького. Львів, 2010. Т. 12, № 2(44),ч. 3. С. 275-279.

Хмельничий Леонтій Михайлович, доктор с.--. наук, профессор

Анісімова Ольга Анатоліївна, студентка магістратури біолого-технологічного фракультету

Компанець геор Олегович, студент магістратури біолого-технологічного фракультету

Лемешко Димитрій Олександрович, студент магістратури біолого-технологічного фракультету

Перекута Олександра Іванівна, студентка магістратури біолого-технологічного фракультету

Сумський національний аграрний університет (Суми, Україна)

Фенотипова консолідованість корів-первісток української червоно-рябої молочної породи різних генеалогічних формувань за екстер'єрним типом

Досліджувалася фенотипова консолідованість корів-первісток української червоно-рябої молочної породи різних ліній за екстер'єрним типом. Оиінювали корів за методикою лінійної класифікації у стаді племінного заводу ПСП „Пісківське" Бахмацького району Чернігівської області. Ступінь фенотипової консолідованості ліній визначали за формулами Ю.П. Полупана (2005). Незалежно від представництва лінії виявлено самий високий ступінь фенотипової консолідації за комплексом ознак, що характеризують вим'я з коефріціентами у межах від K=0,200 (лінія Інгансе) до K=0,393 (лінія Кевеліе). За комплексом екстер'єрних ознак, що характеризують вираженість молочного типу корів найкраще консолідовані дочірні нащадки ліній Інгансе $(K=0,309)$ та Кевеліе $(K=0,335)$. Низьким ступенем фенотипової консолідації за комплексом статей молочного типу відрізняються нащадки двох заводських ліній Сітейшна $(K=0,015)$ і Р.Соверінга $(K=0,049)$. Аналогічна ситуація при визначенні ступеня фенотипової консолідованості спостерігається за групою статей, що характеризують розвиток тулуба. Краще консолідовані тварини ліній Інгансе $(K=0,267)$ та Кевеліе $(K=0,395)$, а найгірше - лінії Сітейшна $(K=0,048)$ та Валіанта $(K=0,042)$. За оцінкою описових ознак у межах досліджуваних ліній додатними значеннями коефіиіентів френотипової консолідованості вирізняються наступні статі: висота у крижах ( $K=0,127-273)$, глибина тулуба $(K=0,092-0,328)$, ширина заду (K=0,033-0,363), прикріплення передньої частини вимені (K=0,041-0227), молочний характер $(K=0,143-0,385)$, а від'ємними - стан ратиць $(K=-0,264 \ldots-0,046)$. Аналізуючи результати досліджень, можна стверджувати, що практичне застосування коефріцієнтів фенотипової консолідації у якості об'єктивних критеріїв оцінки дозволяє у перспективі контролювати процеси консолідації генеалогічних формувань та інших селекційних груп тварин як за екстер'єрним типом, так і за іншими селекційними ознаками.

Ключові слова: українська червоно-ряба молочна порода, лінія, корова-первістка, фенотипова консолідованість, лінійна оцінка, екстер'єр.

Дата надходження до редакції: 09.11.2020 p. 